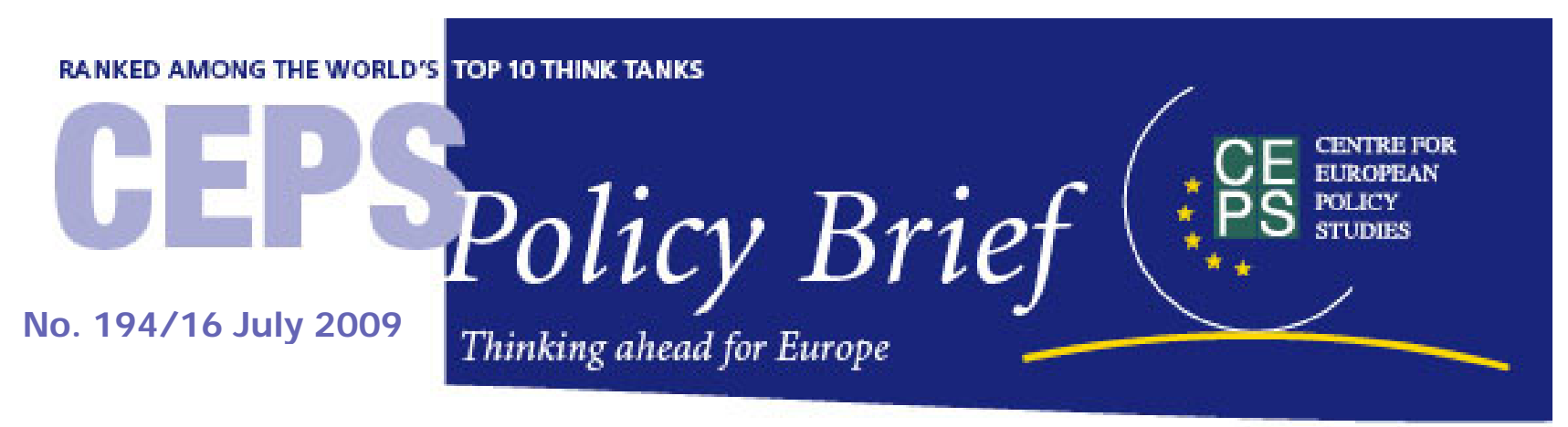

\title{
Why Europe will suffer more Daniel Gros
}

$\mathrm{E}$ uropeans have a tendency to call the financial crisis a US problem, or a crisis precipitated by the 'Anglo-Saxon' model. The data suggest otherwise. Moreover, the corporate sector in Europe has a much lower capacity to finance investment from internal sources of funds, which implies that a recovery of investment in Europe will be much more difficult than in the US, as long as the banking sector remains weakened by excessive levels of leverage. The cost of the crisis could thus be much larger in Europe than in the US.

The literature on financial crises has demonstrated that almost all major crises have been preceded by a combination of two phenomena: an increase in leverage (or credit expansion) and an unusual increase in asset prices. ${ }^{1}$ These two alarm signals could be observed not only in the US but in Europe as well. Yet, unfortunately, they were largely ignored on both sides of the Atlantic. ${ }^{2}$ And, contrary to a widespread perception, Europe accumulated more imbalances than the US. Moreover, the higher reliance of the European corporate sector on external financing suggests that it will take longer for Europe to recover.

It is instructive to look more closely at both indicators of looming financial instability separately: a) credit expansion (or leverage) and $b$ ) the asset price bubble.

\section{Credit expansion}

Generally low standards of risk aversion invite financial institutions to increase credit, which happened on a large scale on both sides of the Atlantic. Excessive levels of leverage are an essential

\footnotetext{
1 See for example Adalid \& Detken (2007) or Alessi \& Detken (2009).

2 See de Grauwe \& Gros (2009) and Carmassi et al. (forthcoming) on the reasons for this.
}

ingredient of most crises and the present one constitutes no exception. Leverage is defined in financial markets as the ratio of debt to equity financing. A higher level of leverage indicates in general a lower capacity to absorb losses and hence greater fragility. In macroeconomic terms, leverage is better defined as the ratio of credit to GDP.

Leverage defined this way increases when credit expands, but prices for goods and services remain stable so that nominal GDP does not increase. ${ }^{3}$ A high level of leverage is an essential ingredient in any major financial crisis because it means that many agents have issued promises to pay a certain nominal amount but do not necessarily have the 'expected' regular cash flow to honour these promises (see Minsky, 2008, for the classical description of leverage schemes leading systems towards instability). Since regular cash flows will be proportional to GDP, macroeconomic leverage can be measured by relating the stock of credit to GDP. It is not possible to establish an absolute benchmark for leverage, as different financial systems can support quite different ratios of credit to GDP. However, changes over time, especially rapid increases in this ratio, constitute alarm signals which have been identified as reliable predictors of financial crisis.

This warning signal was certainly flashing in Europe before 2007-08. ${ }^{4}$ The increase in overall leverage,

\footnotetext{
3 According to Borio \& Lowe (2002), a low inflation environment increases the likelihood that excess demand pressures show up in the form of credit growth and asset price bubbles rather than in goods price inflation. If this is the case, inflation-targeting central banks with a 'myopic behaviour' could contribute to financial instability (see de Grauwe, 2009, and de Grauwe \& Gros, 2009).

${ }^{4}$ We leave aside the question why the build-up of the credit boom was ignored. Inflation-targeting by central banks was
}

CEPS Policy Briefs present concise, policy-oriented analyses of topical issues in European affairs, with the aim of interjecting the views of CEPS researchers and associates into the policy-making process in a timely fashion. Unless otherwise indicated, the views expressed are attributable only to the author in a personal capacity and not to any institution with which he is associated.

Daniel Gros is Director of the Centre for European Policy Studies in Brussels. He is grateful to Cinzia Alcidi for excellent research assistance and to Paul De Grauwe and Peer Ritter for valuable comments. 
measured by the debt-to-GDP ratio, was broadly similar to the one experienced in the US; only its distribution over different sectors was different. The set of tables below (1a and $1 \mathrm{~b}$ ) shows these stylised facts.

A first key observation is that the increase in overall (economy-wide) leverage has always been higher in the euro area (EA) than in the US. The increase between 1999 and (end) 2007 was around 100\% of GDP for the EA, while in the US it amounted 'only' to $80 \%$ of GDP. Similarly leverage in the nonfinancial corporate sector increased by more (25\% of GDP, 1999 to end 2007) in the EA, than in the US (where the increase was only $3 \%$ ).

Table 1. Debt-to-GDP ratios

\begin{tabular}{|l|r|r|r|r|}
\hline & \multicolumn{2}{|c|}{ a) Economy-wide } & \multicolumn{2}{c|}{$\begin{array}{l}\text { b) Non-financial } \\
\text { corporate sector }\end{array}$} \\
\hline & \multicolumn{1}{|c|}{ EA } & \multicolumn{1}{c|}{ US } & \multicolumn{1}{c|}{ EA } & \multicolumn{1}{c|}{ US } \\
\hline 1999 & 3.51 & 2.66 & 0.67 & 0.46 \\
\hline 2007 & 4.54 & 3.47 & 0.92 & 0.49 \\
\hline 2008 & 4.73 & 3.46 & 0.97 & 0.49 \\
\hline $\begin{array}{l}\text { Change } \\
1999-2007\end{array}$ & 1.03 & 0.81 & 0.25 & 0.03 \\
\hline
\end{tabular}

Notes: Economy-wide includes households, non-financial companies, the financial sector and government. Debt is the sum of securities and loans by the non-financial sector and banks or non-monetary financial institutions (MFIs).

Sources: ECB statistical data Warehouse, Euro Area Accounts, balance sheet \& Federal Reserve Z1, March 2009.

Yet, the most relevant differences between the US and the euro area come in the leverage of households and the financial sector. As one would expect, leverage increased considerably in the US household sector ( $40 \%$ of GDP) but increased very little in the euro area.

A surprising further, important difference between the EA and the US is that financial sector leverage is at a much higher level in the euro area and increased by much more (about $70 \%$ of GDP compared to $40 \%$ in the US). This is the key underlying cause of the widespread stress in the European banking system. The crisis might have originated in the US, but the

probably one key reason. According to Borio \& Lowe (2002), a low-inflation environment increases the likelihood that excess demand pressures show up in the form of credit growth and asset prices bubble rather than in goods price inflation. If this is the case, inflation-targeting central banks with a 'myopic behaviour' could contribute to financial instability (see de Grauwe, 2009, and de Grauwe \& Gros, 2009).
European financial sector was very fragile and exposed to losses from US (and other) assets.

Table 2. Debt-to-GDP ratios

\begin{tabular}{|l|r|r|r|r|}
\hline & \multicolumn{2}{|l|}{ c) Financial sector } & \multicolumn{2}{c|}{$\begin{array}{l}\text { d) Households } \\
\text { \& small business }\end{array}$} \\
\hline & \multicolumn{1}{|c|}{ EA } & \multicolumn{1}{c|}{ US } & EA & \multicolumn{1}{c|}{ US } \\
\hline 1999 & 1.61 & 0.79 & 0.48 & 0.88 \\
\hline 2007 & 2.32 & 1.17 & 0.61 & 1.28 \\
\hline 2008 & 2.42 & 1.17 & 0.61 & 1.24 \\
\hline $\begin{array}{l}\text { Change } \\
1999-2007\end{array}$ & $\mathbf{0 . 7 1}$ & $\mathbf{0 . 3 8}$ & $\mathbf{0 . 1 3}$ & $\mathbf{0 . 4}$ \\
\hline
\end{tabular}

Note: The financial sector in the EA is defined as MFIs, insurance corporations and pension funds and other financial intermediaries including financial auxiliaries. MFIs' debt is given by debt securities issued plus currency and deposits.

Sources: ECB Statistical data Warehouse, balance sheet \& Federal Reserve Z1. March 2009.

\section{Asset price bubble}

Another reason why Europe was as exposed as the US to this crisis is that Europe experienced the same real estate price bubble as the US. Figure 1 shows this using the ratio of house prices to rents which (like the price/earnings ratio for stocks) should be stable over longer periods. ${ }^{5}$ It is apparent that since the mid-1990s house prices have increased by almost exactly the same relative amount, reaching an unprecedented level on both sides of the Atlantic. The main difference between the US and the euro area is only that since 2006-07 house prices have declined more in the US.

This suggests that on average the euro area suffers from the same crisis symptoms as the US in terms of leverage and a house price bubble. It was only the trigger event of the crisis that took place in the US.

The comparison undertaken here is mainly between the US and the euro area because of data availability and because both are of a similar size. The data for the UK show similar symptoms: leverage increased as well and house prices increased by as much as in the euro area.

\footnotetext{
${ }^{5}$ When looking at house prices in nominal terms, the CaseShiller index is the one most used. However, this exhibits quite high volatility if compared to the OECD index. In 1999 the two indices were at the same level (about 92), but by 2006 the Case-Shiller index increased by about 250\%, while the OECD one, at its peak in 2007, had not even doubled. At the end of 2008, the two indices were again back to a similar level (just above 150).
} 


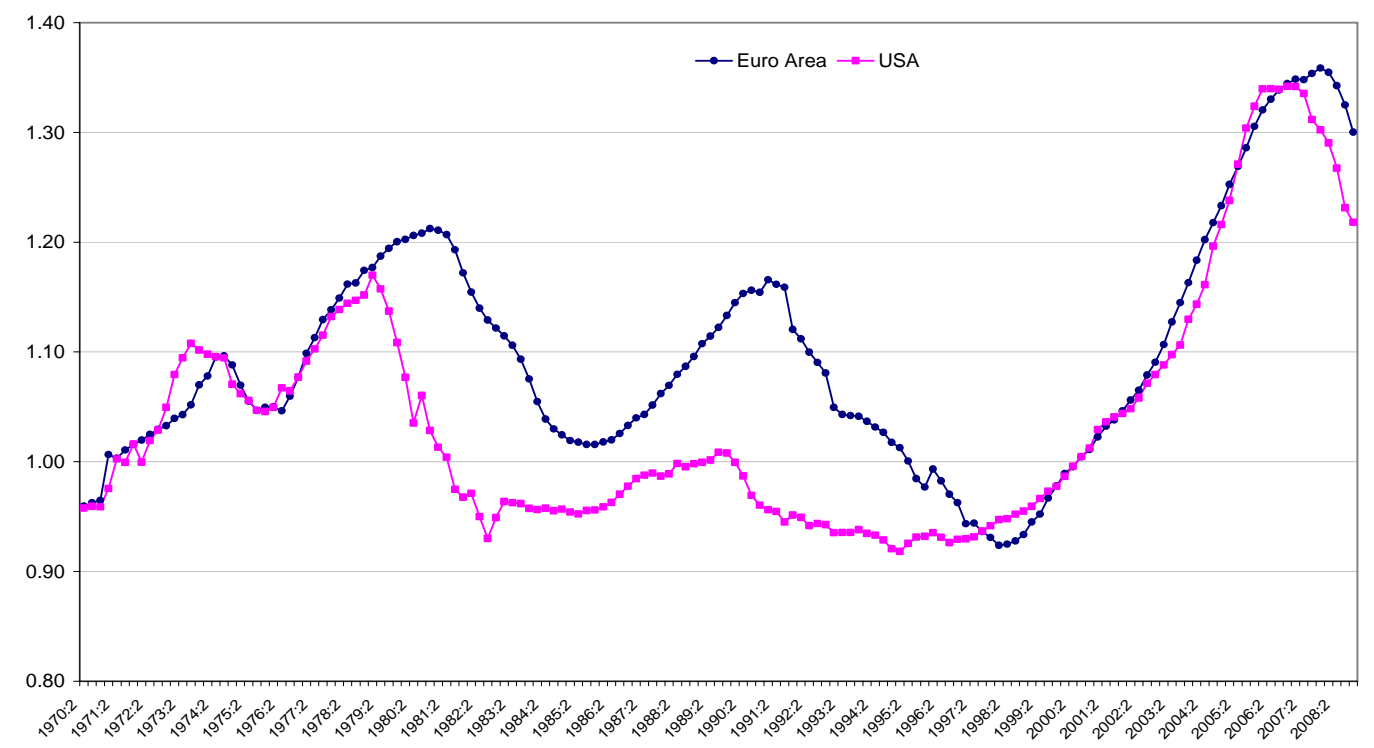

Note: Euro area index is defined as the weighted average (by GDP) of Germany, France, Italy, Spain, Finland, Ireland and the Netherlands.

Source: OECD, May 2009, and own computations.

Data are scarce on house prices for the new member states and their case it is much more difficult to establish a longer-term historical norm against which to judge the housing sector. In some of the smaller new member states (especially in the Baltics and the Balkans), however, it is clear that large house price and construction bubbles emerged and have now burst leading to very sharp contractions in economic activity.

All in all it would thus appear that the average for the full EU-27 would not be much different in terms of house prices and leverage increases from the euro area average. However, the euro area averages hide important differences across countries, both in terms of leverage and house prices.

Figures 2 and 3 show the relevant variables. Figure 2 shows that within the euro area there are enormous differences in terms of the evolution of house prices (relative to rents), which have been stable in Germany but increased by over $80 \%$ (and thus more than in the US) in France and Spain.

A similar picture emerges when one looks at leverage yields. The evolution of credit growth shows similar differences: leverage (as measured by MFI assets relative to GDP) was high, but stable in Germany, whereas it increased considerably in those countries where house prices increased (most in France and Spain) ${ }^{6}$

\footnotetext{
${ }^{6}$ At first sight, it might thus be surprising that the German banking system was also hard hit by the crisis. But the German banking system was affected also because it
}

This analysis focuses on the eurozone average. The large differences within the eurozone are probably due to a combination of a fundamental asymmetry in the initial conditions between Germany and the rest of the members and differences in the structure of national financial markets. The fundamental asymmetry in initial conditions was created by the construction boom in Germany following unification. This boom peaked in 1995, when construction constituted about $14 \%$ of that country's GDP. At this point wages also started to increase, which in turn led the Bundesbank to hike interest rates considerably, thus precipitating currency crisis throughout Europe and triggering a sharp recession. From 1995 the German economy remained weak as its construction sector contracted slowly but continuously until about 2005 (when it had shrunk to about $8 \%$ of GDP). By contrast, other countries in the eurozone experienced a real estate boom over this period with rising house prices and increasing construction activity supported by the lower interest rates brought about by the euro. Different characteristics in national financial markets (e.g. the availability of mortgages indexed on shortterm rates, different loan-to-value ratios, etc.) meant that this easing of financial conditions had quite differentiated impacts on different member countries. ${ }^{7}$

intermediated the large current account surplus of the country by investing in what appeared then as a most promising instrument, namely US securitised household debt. German banks, and thus also indirectly German savers, had to take large losses when the US bubble burst.

${ }^{7}$ See Gros (forthcoming) and Calza et al. (2009). 
Figure 2. House prices: Price-rent ratios

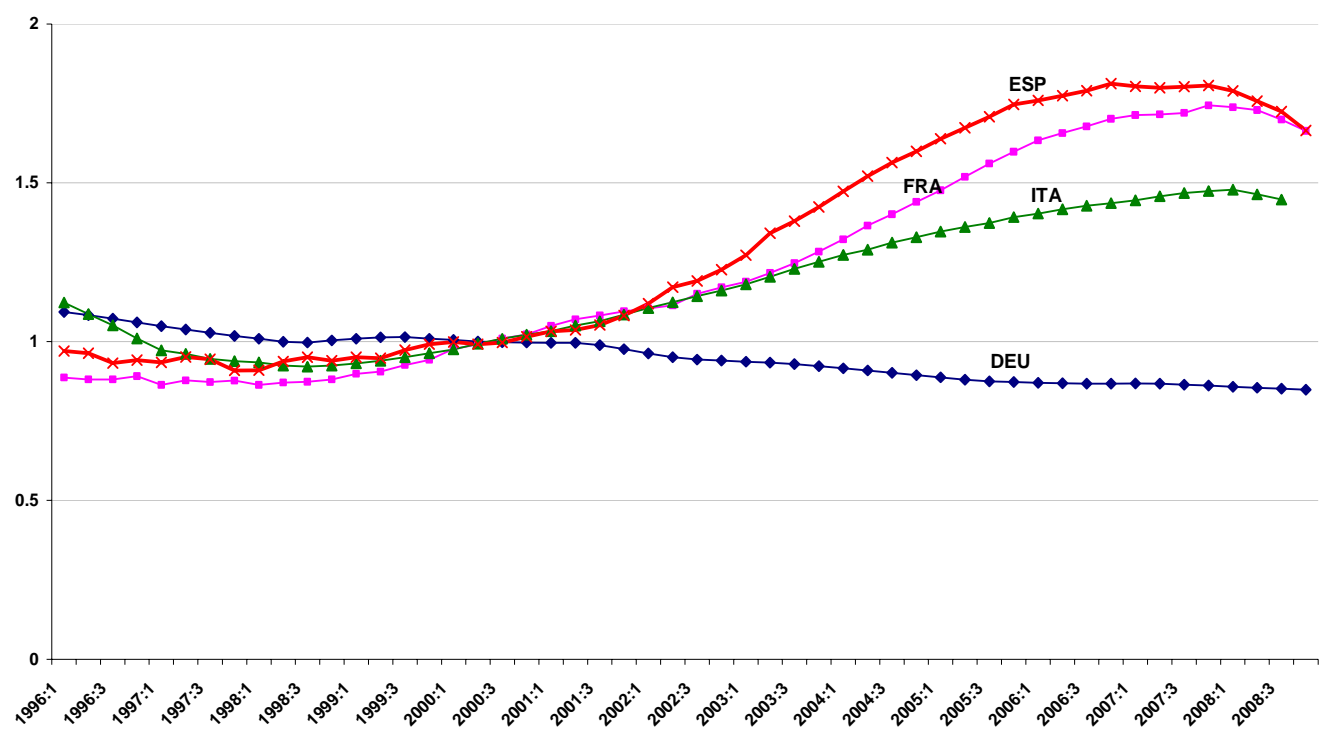

Source: OECD, May 2009.

Figure 3. Total MFIș' liabilities other than capital and reserves.(relative to GDP)

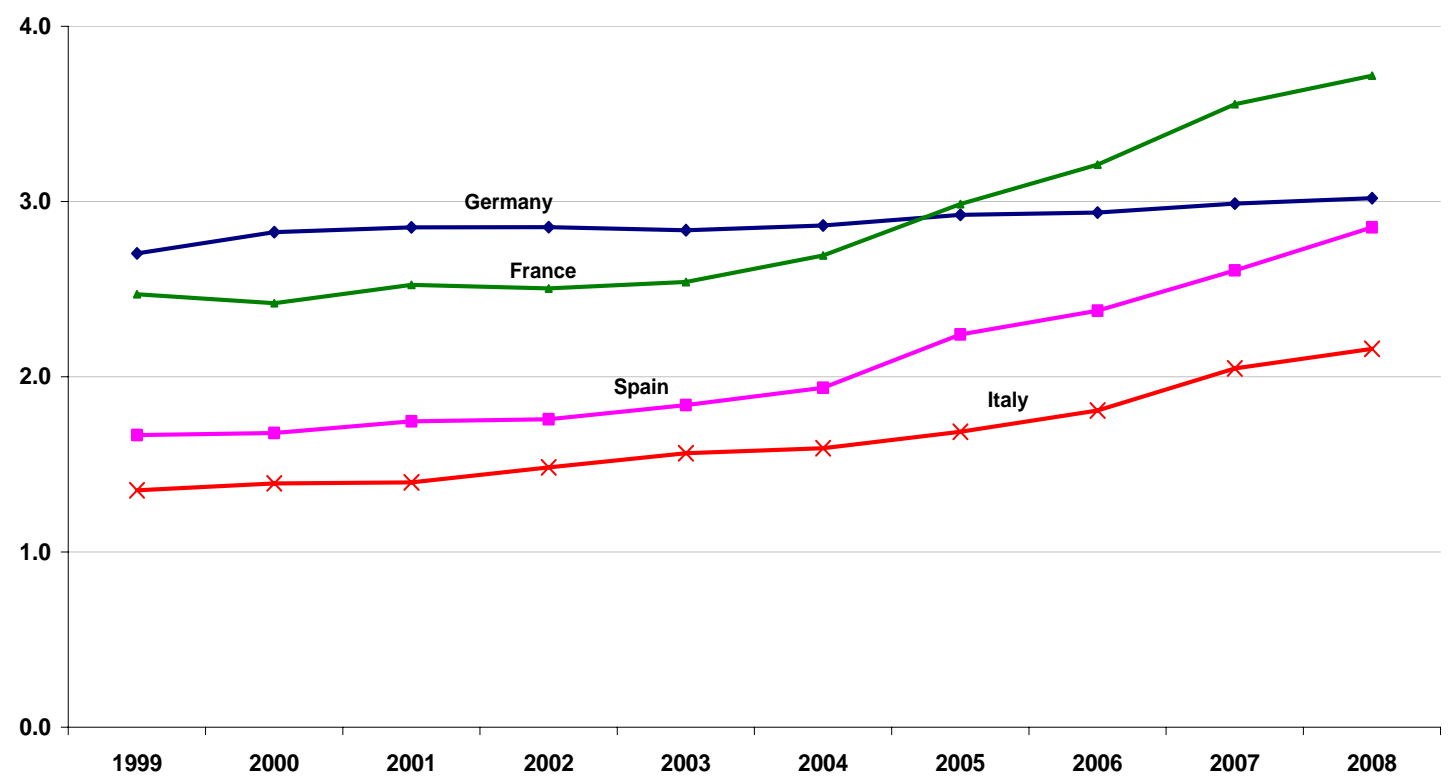

Sources: ECB Statistical data Warehouse, MFIs’ accounts.

The importance of the financial sector to investment

A financial system that needs to reduce leverage has a tendency to restrict the availability of credit. How important is this to the economy? This depends of course on the financing needs of the various sectors in the economy. European consumers traditionally have been large savers (with the exception of Spain). They do not need credit to maintain consumption.
However, the corporate sector is in a completely different situation. It typically needs access to external financing to maintain investment. But in this area again it appears that the situation in the US is better.

Figure 4 below shows that during most of the past decade, the US corporate sector had a much smaller financing gap than did the European sector. During the first quarter of 2009, the US corporate sector actually became a net saver because its profits (or rather the net cash flows from current operations) were larger than expenditure for investment. This

\section{4 | Daniel Gros}


implies that from now on, the US corporate sector does not need to receive new credit (from banks or other sources) in order to maintain investment at least at the present level. There are of course large differences within the US corporate sector, with some parts registering a large cash flow surplus (e.g. the tech sector) and other parts (e.g. the automobile sector), a large deficit. But the commercial paper market, which continues to function, can recycle the surplus funds for enterprises such as Microsoft to those firms in need of funds.
The situation in the European corporate sector is quite different. It can finance only about one-third of all investment from internal sources and thus has still has a considerable financing gap of around $6 \%$ of its value added. This implies that the corporate sector in the euro area needs a continuing flow of new credit just in order to keep investment going at the present level. Europe thus faces the unpleasant reality of having a financial sector with a stronger need for deleveraging in combination with a corporate sector that is more dependent on external finance than the US.

\section{Figure 4. Financing need of the corporate sector}

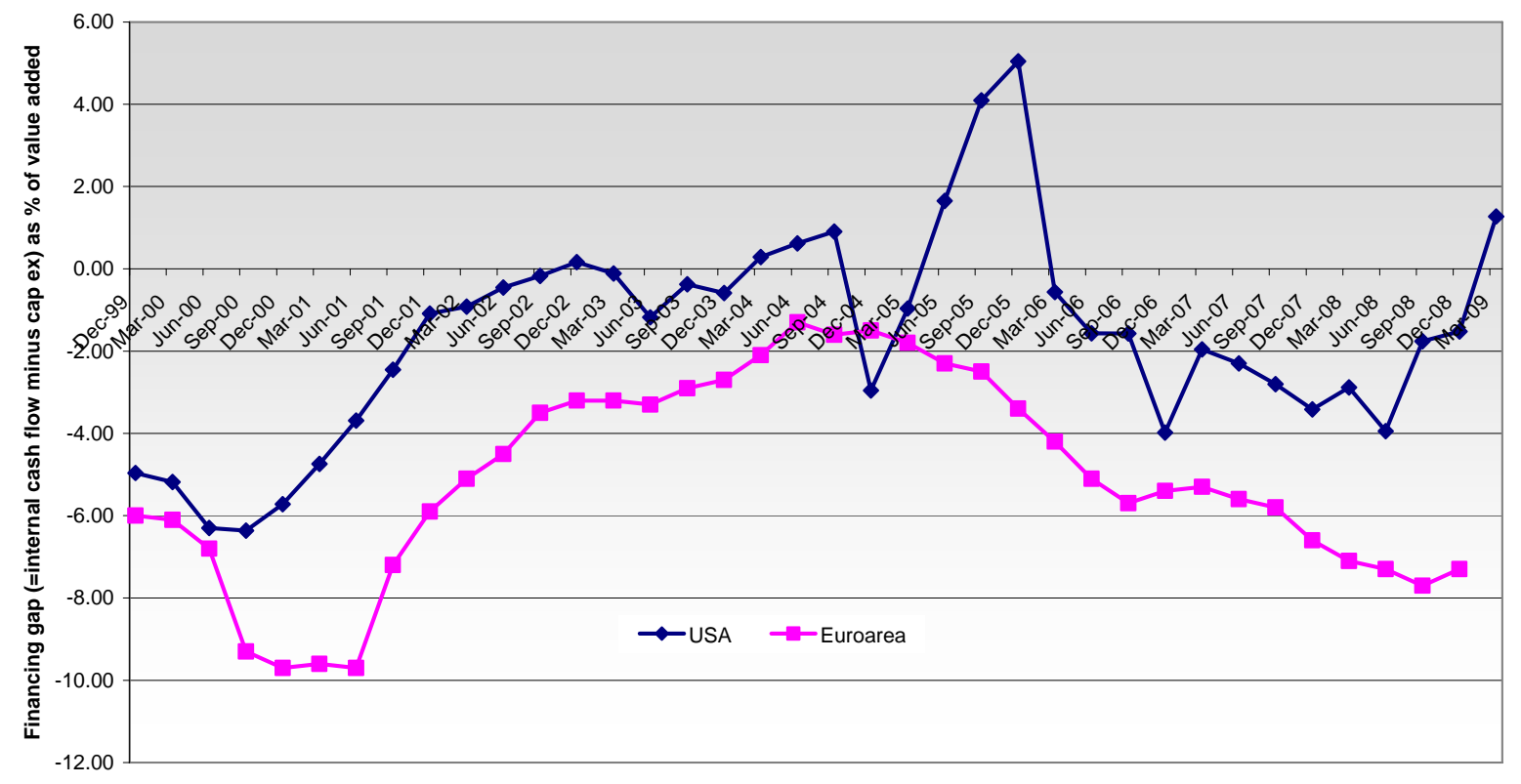

\section{Conclusions}

This crisis has often been labelled a 'US crisis' and European policy-makers still have a tendency to argue that this crisis started in the US and that Europe was an innocent bystander which was hit only because financial markets are integrated. This attitude is of course politically convenient because it implies that European policy-makers have no responsibility for this crisis. However, the numbers tell a different story: an unprecedented level of credit was allowed to develop in Europe.

This crisis might have started in the US, but even more combustible material had accumulated in Europe, so that it likely that the cost will be higher here and the recovery slower than on the other side of the Atlantic.

Costello et al. (2009) suggest that this crisis might lead to a considerable fall in potential output for the eurozone. This seems indeed highly likely considering the European combination of a highly leveraged financial sector and a corporate sector dependent on external financing.
What does this analysis imply for macroeconomic policy? At first sight, one might be tempted to argue that the need for expansionary policies is even stronger in Europe than in the US. But this is not as straightforward as one might think.

An expansionary fiscal policy is useful, especially in the US because it can 'substitute' for falling demand for household construction and sustain consumption (via transfers to households). In Europe deficit spending also might sustain demand, but this cannot really substitute for the missing investment that translates into a lower future capital stock and lower productivity growth. In Europe particular care should thus be taken not to crowd out private investment, which is already weakened by difficult access to credit.

On monetary policy, the need for an expansionary policy is also evident, but one again has to think about what the ultimate aim is. In the US the ultimate aim of policy is to lower interest rates. The central bank can directly control only short-term interest rates, which it 
has driven to very close to zero. But longer-term interest rates are determined in the market for longer term securities. Hence the Federal Reserve has embarked on a programme to buy $\mathrm{T}$ bills, a policy that is also called quantitative easing (QE). The analysis presented here suggests that in the EU the key problem might be the availability of credit, not the level of longer-term interest rates. It thus makes sense that the ECB has so far refused to push its policy interest rate to zero. But the ECB has also

\section{References}

Agnello, Luca and Ludger Schuknecht (2009), Booms and busts in housing markets: determinants and implications, ECB Working Paper No. 1071, European Central Bank, Frankfurt, July.

Adalid, R. and C. Detken (2007), Liquidity shocks and asset price boom/bust cycles, ECB Working Paper No. 732, European Central Bank, Frankfurt, February.

Alessandrini, P. and M. Fratianni (2009), "International monies, special drawing rights, and supranational money”, mimeo, 29 June.

Alessi, L. and C. Detken (2009), 'Real time' early warning indicators for costly asset price boom/bust cycles: A role for global liquidity, ECB Working Paper No. 1039, European Central Bank, Frankfurt, March.

Borio, C. and Ph. Lowe (2002), Asset prices, financial and monetary stability: exploring the nexus, BIS Working Paper No. 114, Bank for International Settlements, Basel.

Calza, Alessandro, Tommaso Monacelli, and Livio Stracca (2009), Housing finance and monetary policy, ECB Working Paper No. 1063, European Central Bank, Frankfurt, July. implemented its own version of quantitative easing by lending banks an unprecedented amount (over $€ 400$ billion, much more than the Fed has done in terms of $\mathrm{QE})$ at its policy rate (1\%) for a maturity of one year.

Our analysis suggests that this is the right approach and that probably further QE of this type is needed in Europe until lending conditions return to normal.

Carmassi, Jacobo, Daniel Gros and Stefano Micossi (forthcoming), "Causes of financial instability and the remedy: Keep it simple", Journal of Common Market Studies, forthcoming special issue on the financial crisis.

Costello, D. with A. Hobza, G.J. Koopman, K. Mc Morrow, G. Mourre and I.P. Székely (2009), "EU reforms to increase potential output", Voxeu.org, 15 July (http://www.voxeu.org /index.php?q=node/3771).

De Grauwe, P. (2009), Keynes' Savings Paradox, Fisher's Debt Deflation and the Banking Crisis, CEPS Working Document No.319, CEPS; forthcoming July.

De Grauwe, P. and D. Gros (2009), A New Two-Pillar Strategy for the ECB, CEPS Policy Brief No. 191, CEPS, June 2009.

Gros, Daniel (forthcoming), "Comments” on Charles Wyplosz, "Ten Years of EMU: Successes and Puzzles”, prepared for the Conference "Spain in EMU", organised by Banco de España, Madrid, 27 February 2009.

Minsky, H. (2008), Stabilizing an unstable economy, McGraw Hill. 


\section{Annex: The credit boom over time}

Not only has the leverage of the financial sector (and of the economy as whole) increased by more in the euro area than in the US, over time it also exhibits higher volatility. Figures A1 and A2 show the first difference of the leverage indicators for the various sectors already used for Tables 1 and 2 above. Figure A1 shows that in the US leverage started to increase considerably already in 2001, with the pace actually somewhat declining over time (except for the spike in 2007). By contrast Figure A2 shows that in the euro area leverage really took off only after 2004, but then at increased rates (at around 20\% per annum), which are usually associated with credit booms in emerging markets.

Figure A1. The growth of US leverage indicators over the last decade

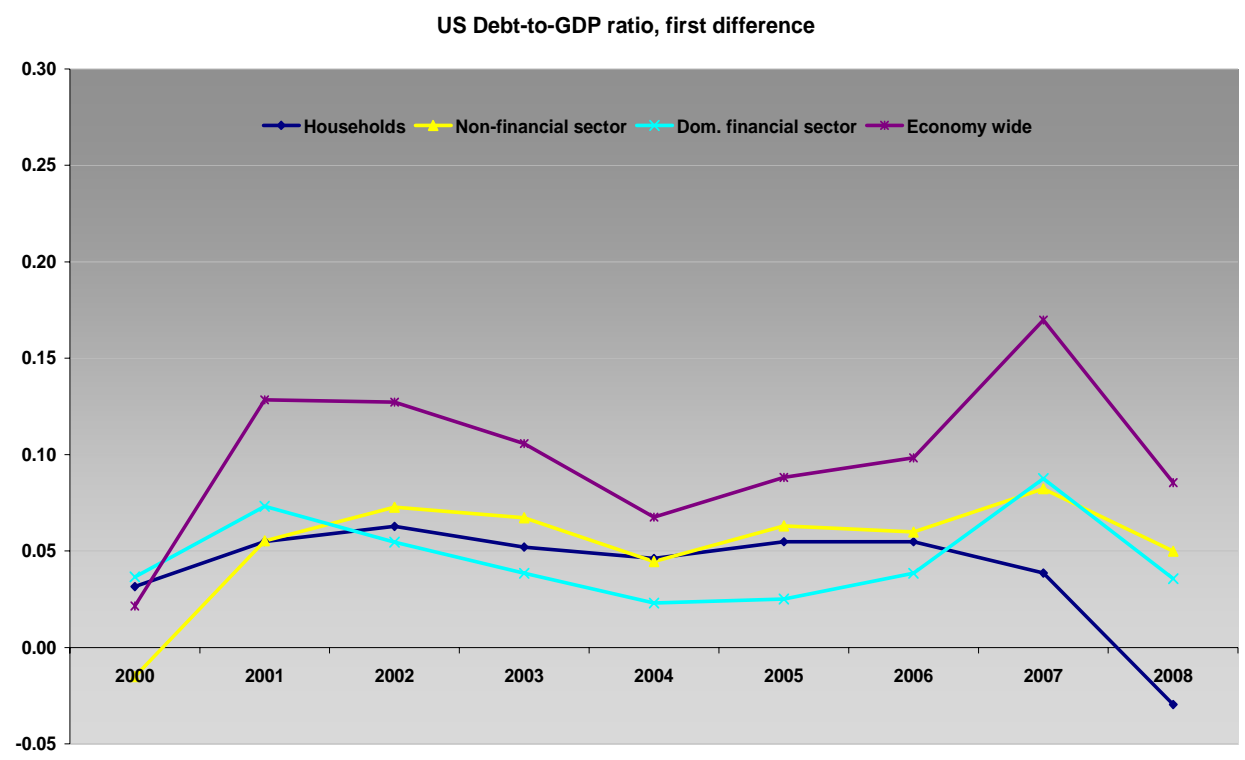

Figure A2. The growth of leverage indicators in the euro area over the last decade

EA Debt-to-GDP: first difference

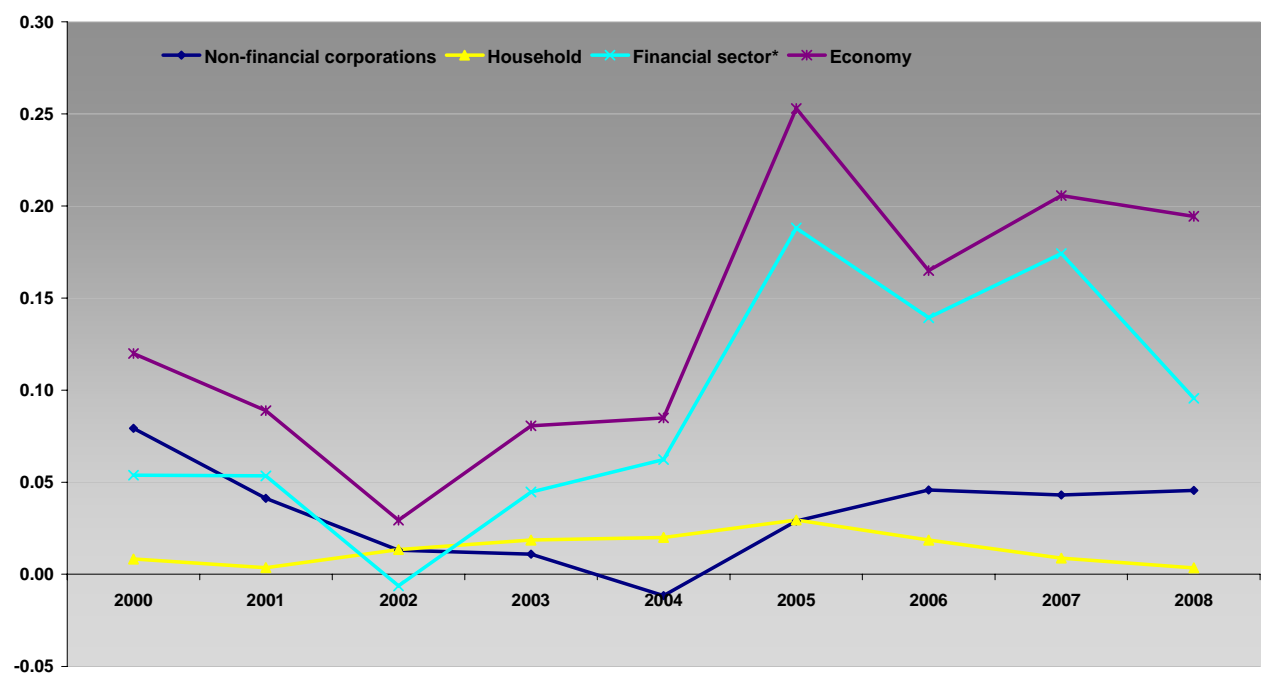




\section{About CEPS}

Founded in Brussels in 1983, the Centre for European Policy Studies (CEPS) is among the most experienced and authoritative think tanks operating in the European Union today. CEPS serves as a leading forum for debate on EU affairs, but its most distinguishing feature lies in its strong in-house research capacity, complemented by an extensive network of partner institutes throughout the world.

\section{Goals}

- To carry out state-of-the-art policy research leading to solutions to the challenges facing Europe today.

- To achieve high standards of academic excellence and maintain unqualified independence.

- To provide a forum for discussion among all stakeholders in the European policy process.

- To build collaborative networks of researchers, policy-makers and business representatives across the whole of Europe.

- To disseminate our findings and views through a regular flow of publications and public events.

\section{Assets}

- Complete independence to set its own research priorities and freedom from any outside influence.

- Formation of nine different research networks, comprising research institutes from throughout Europe and beyond, to complement and consolidate CEPS research expertise and to greatly extend its outreach.

- An extensive membership base of some 120 Corporate Members and 130 Institutional Members, which provide expertise and practical experience and act as a sounding board for the utility and feasability of CEPS policy proposals.

\section{CEPS carries out its research via its own in-house} research programmes and through collaborative research networks involving the active participation of other highly reputable institutes and specialists.

\section{Research Programmes}

Economic \& Social Welfare Policies

Energy, Climate Change \& Sustainable Development

EU Neighbourhood, Foreign \& Security Policy

Financial Markets \& Taxation

Justice \& Home Affairs

Politics \& European Institutions

Regulatory Affairs

Trade, Development \& Agricultural Policy

\section{Research Networks/Joint Initiatives}

Changing Landscape of Security \& Liberty (CHALLENGE)

European Capital Markets Institute (ECMI)

European Climate Platform (ECP)

European Credit Research Institute (ECRI)

European Network of Agricultural \& Rural Policy Research Institutes (ENARPRI)

European Network for Better Regulation (ENBR)

European Network of Economic Policy Research Institutes (ENEPRI)

European Policy Institutes Network (EPIN)

European Security Forum (ESF)

CEPS also organises a variety of activities and special events, involving its members and other stakeholders in the European policy debate, national and EU-level policy-makers, academics, corporate executives, NGOs and the media. CEPS' funding is obtained from a variety of sources, including membership fees, project research, foundation grants, conferences fees, publication sales and an annual grant from the European Commission.

E-mail: info@ceps.be

Website: http://www.ceps.be

Bookshop: http://shop.ceps.be 